\title{
The Role of the Higher Education in the Development of the Agriculture
}

\author{
Péter Miklós Kőmíves, Péter Pilishegyi, Norbert Novák, Adrián Szilárd Nagy, and Péter Körösparti
}

\begin{abstract}
The aim of our article is to show the importance of the agriculture in the global life. One of the most important challenges of the world to produce enough food for the growing population of the Earth. The food production needs to be increased not only because of the growth in population but also because of the changing dietary habits. While the agriculture tries to produce more food they have to solve several problems. Increasing need for water, soil degradation and climate change these are only a few of the most important problems we are facing right now. We have to increase the agricultural production on less arable land - but the question is: how?

The role of education and especially the agricultural education became much more important in this case. Prior researches showed that for the improvement in the skills and knowledge of the farmers and agricultural employees we have to analyse the actual situation and challenges of the agricultural education. To serve the needs of the precision agriculture, the educational system have to pay attention for the changing needs of the agricultural system.

During the reform of higher education and the agricultural higher education the most actual developments have to be included in the curricula. The labour market wants the higher education to offer actual knowledge for the students and for professionals as well during formal, informal and non-formal education as well. As the technology used by agriculture is continuously developing the employees and the farmers need different courses as parts of the lifelong learning systems.
\end{abstract}

Index Terms-Agriculture, Bologna process, development, higher education.

\section{INTRODUCTION}

In order to harmonize the connection of higher educational systems of Hungary and the other European Union member states the Hungarian government decided to introduce the Bologna system after 2006. As a part of the legislation the government and the Parliament of Hungary decided to reform the whole system not only in a theoretical way but in practice as well. The system reform had several impacts: the number of the students studying in Hungary raised radically - the so called mass higher education has been introduced in the country. The new system has been formed as a multi-level,

Manuscript received February 7 2019; revised June 23, 2019. Supported BY the ÚNKP-18-3 New National Excellence Program of the Ministry of Human Capacities"

P. M. Kőmíves, N. Novák, and A. Sz are with the University of Debrecen, Faculty of Economics and Business, Debrecen, H-4032, Hungary (e-mail: komives.peter.mikos@econ.unideb.hu, novak.norbert@econ.unideb.hu, nagy.adrian@econ.unideb.hu).

P. Pilishegyi and P. Körösparti are with the University of Debrecen, Centre of Student Services and Relations, Debrecen, H-4032, Hungary (e-mail: ppilishe@gmail.com, pkorosp@gmail.com). linear system consisting vocational training, bachelor training, master training and doctoral training as well. As a part of the reform the Hungarian higher education became truly international however it already had decades of experience in it [1]. The original idea separated the different aims and functions of the higher education between the different stages of the three-tier system. The aim of the bachelor trainings was to serve the basic needs of the labour market. The role of the master trainings was more important: to produce professionals with significant knowledge and partly leadership skills who are able to complete scientific and development trainings. And last but not least the role of the doctoral (PhD or DLA) trainings was to train young scientists who can complete the most important basic research [2].

Agricultural education means the teaching of different skills and knowledge related to the agriculture aimed to educate students for entry level jobs and later more education for advanced agricultural jobs [3]. The agricultural higher educational institutions and the big universities with agricultural faculties has a very important role in teaching specialists for the agricultural labour market and in training entrepreneurs with farming skills and knowledge [4]. This way the degree holder bachelors or masters can easily find a job as an employee or start their own businesses. Nowadays the agricultural education on every level has to give the skills for the students which are making them able to detect the interconnectedness of different information regarding to the parts of the agriculture. That means information is coming from different sources and the agricultural professionals have to be able to analyse and evaluate the relevant information during their work wherever they are working [5].

It is extremely important to serve the changing needs of the agriculture because the global agricultural sector will face many challenges in the following decades. Without specialists who own the actual knowledge it is impossible to solve these questions and achieve their purpose. Without education the farmers are not able to achieve the goals coming from the changing market and customers' needs.

\section{Global Challenges of the Agriculture}

The population of the Earth is continuously growing and in the next 40 years the agricultural production have to be raised by $60 \%$ in order to cover the needs caused by the changing dietary habits and with the growing number of people who has enough money to buy food with more added value [6]. In several countries' agriculture and the food industry the habits have to be changed and the focus has to move on not only quantity but quality as well. The Hungarian agricultural system faced these challenges at the beginning of the 1990's 
[7]. Unfortunately in several countries or regions suffering from hunger and malnutrition caused by political conflicts, soil degradation, climate change or other reasons is still a big problem for the population and for the agriculture as well [8].

On the other hand the agriculture has to produce more food on less available soil. That means it is crucial to raise the efficiency of the agriculture in the next decades to serve the increasing need for food and to stop hunger [9]. In order to increase the productivity of the agriculture the farmers have to apply the novel innovations of the precision agriculture. The use of these innovations may depend on several factors including internal and external ones as well. We can name the limited fiscal possibilities of the famers and their knowledge and agricultural skills as internal factors. The external factors are mostly coming from the impact of the novel technologies. The farmers are trying to realize benefits from the use of precision technologies which may lead to the reduction of information asymmetry caused by the natural production systems [10]. The effectiveness of the use of precision agriculture systems mostly depend on the farm size, the variety of crops produced by the farm, the mix of technology used by the farm and on the knowledge and info-communication technology knowledge of the farmers [11]. The knowledge and the skills of the employees employed by agricultural companies are crucial when the management wants to increase the production, the effectiveness and the profit earned by the company. On the other hand the employees often overrate their knowledge on info-communication technologies when they think their knowledge is larger and more actual than it is in reality [12]. The productivity and the effectiveness of the agriculture have to be raised by using the novel findings of the research and development activities associated to agriculture [13]. In the developed countries every 100 USD GDP growth caused by the agriculture is linked to about 5.5 times more public financed research and development than it has been spent for this reason in countries with medium income. The countries with high income can spend 7 times more on public financed research and development in agriculture than the countries with low income can afford [14], [15]. During the planning of agricultural development - and not only the agricultural research and development - we have to keep in mind many circumstances: the economic status of the country, the environment and the actual social conditions of the country [16]. On the other hand big differences can be detected between money spent on food globally which can also have impacts on the agriculture itself. While in rich countries the families only spend about $10 \%$ of their income on food this share can reach the $50-60 \%$ level in poor countries - mainly located in Africa [17].

As it could be seen from the sources shared above the agriculture have to face many challenges in the next decades. We have to produce more food for people and not only because of the increasing number of the global population but also because of the changing dietary habits. We also have to produce this growing amount of food cheaper to reduce the food prices in the poorest regions of the world. This way in these regions the people could be able to spend more money on other activities and services and - for example - they could have more time for educate themselves. To increase the agricultural production we have to use the newly developed technologies in the agriculture. During the use of these novelties and innovations farmers have to have the most actual knowledge in several fields of agriculture and food production. The use of the new devices and practices more education is needed for farmers and agricultural employees in order to strengthen the needed skills of the people working in any sub-sectors of the agriculture.

Based on Bloom's taxation the modern agricultural education have to develop the students in order to become able to complete the aims listed above in the following areas. First of all the education have to develop their knowledge (or have to complete the cognitive objectives) so the universities have to clarify what they want their students to know. Secondly the education have to develop the students' skills (or have to complete psychomotor objectives) so the universities have to clarify what they want their students to be able to do. And last but not least the education have to develop the students' attitude (or have to complete affective objectives) so the universities have to clarify what they want their students to think or care about [18]. The teachers of the lower level agricultural education and the members of the academic staff in the agricultural higher educational institutions have to possess their knowledge bases for teaching in the following areas: content knowledge, pedagogical knowledge, professional knowledge and pedagogical content knowledge. From the list the last element is named as the most effective piece of the teachers' knowledge during the effective teaching work in the classrooms or auditoriums [19].

\section{Methodology}

The aim of this article is to give a brief overview on the changes of the agricultural higher education in order to live up to the changing expectations of the global agricultural system serving the food needs of the global population. While writing the article we made an extended literature overview as part of the secondary data collection. During the secondary data collection we have to be very careful while we are designing the listed sources we will cite in our publication. The use of published data can make the research faster and cheaper but the reliability of the data used is always a topical issue. When statistical data are not collected directly by the authors but cited from different sources national statistical services and statistical data suppliers from important international organisations (OECD, UN, FAOSTAT, EUROSTAT etc.) can be reliable and safe choices. Preparing a representative data collection is very expensive and the fiscal resources of the research group are often limited so using safe and reliable data can be a suitable and cheap solution to complete research and analysis [20].

In this article which is aimed to give a brief literature overview of the Hungarian and the international agricultural higher educational system we cited several sources. All of them were published in reviewed journals or books by respected authors. We tried to analyse not only the Hungarian situation of the agricultural higher education but in other countries as well. On the other hand we cited reliable 
statistical sources published by the OECD. During the preparation of this article we used critical analysis method in order to compare the different sources.

During the preparation of the article we paid attention for the prescriptions of the international standards of the scientific research. With respect to these regulations and ethical norms we cited all the authors of the articles in the list of sources as it has been accepted by the international scientific life.

\section{THE FORMATION OF THE AgRICULTURAL HigheR EDUCATION}

The agriculture had a very important role in the life of the humankind, however the agriculture as a scientific field did not exist till the beginning of the $19^{\text {th }}$ century, even though several parts of it already existed in other scientific fields - for example in the framework of the biology [21]. Before the scientific nature of the agriculture was recognised and the formal agricultural educational institutions started to operate demonstration farms already have existed since the $17^{\text {th }}$ century and agricultural fairs have became very important forums of knowledge transfer in the agriculture [22]. The agricultural education started in Hungary in the $19^{\text {th }}$ century when the public opinion changed on the whole agriculture itself. Before that period the people usually thought agriculture is a kind of profession sons could learn from their fathers and no formal education needed in this discipline. But in the $19^{\text {th }}$ century scientists agreed that the higher level of education is needed in order to serve the changing needs of the whole society [23]. After several changes the role of tacit knowledge in agricultural education is still very important [22].

However after centuries of practical and absolutely non-formal education in the agriculture the modern viewpoint decided to separate the education from the family level but the farms - and mainly the family farms - didn't lose their relevance in the education. The new approach of education created a more systematic structure of the agricultural education. On the other hand the transformation of the practical knowledge was still organised on farms but in many cases not on the farms of the students' parents [24]. During the strategic planning of the higher education every country have to decide what kind of studies they want to finance. As a part of this planning the state or the government have to clarify the most important data related to the higher education - for example they have to publish the criteria of the student-teacher ratio, the number and ratio of the professors who hold a scientific degree and prescriptions for the technical operation for the higher education. On the other hand from the non-institutional viewpoint the states have to decide who should have the control on the curriculums of the agricultural education. They can delegate this right to the academics or to the users as well. The legislators also have to decide the right content of education in order to follow the changing socio-economic needs formulated by the relevant actors [25].

The educational roles have to be separated between the different nationally financed institutions in order to clarify the main mission of each university or university college. This way the students and the professional partners can also decide where to study, where to educate employees or where to find cooperating partners [26]. The importance of the lexical knowledge in the education reduced while the importance of the scientific and multidisciplinary approach raised. The resilience which makes the students and the higher educational institutions able to develop themselves as fast as it is possible became more and more important as the rapid technological changes used to reform the agricultural systems often [27].

In Hungary the introduction of the three-tier educational system was not that successful in case of the agricultural higher educational programs. Many small bachelor programs has been created with crowded curricula. The outcome of the education was not really clarified by the legislators for the labour market actors. Because of the very intensive curricula the workload of the universities' academic staff became very high and it became very difficult for the students to complete the programs. On other hand the Hungarian agricultural degrees are based upon very intensive and wide knowledge of the students [28]. Unfortunately the newly graduated students are not able to earn enough salary on the labour market which makes the agriculture less attractive for secondary school students [29]. This trend is very harmful for the aging agricultural society and for the agricultural production of Hungary as well because if a sector is not attractive enough for young professionals who decide not to join the labour market based upon their degrees the revitalization of the sector will not be completed on time - if it is even completed at any time.

The higher education in several European countries goes under a very intensive accreditation, evaluation and quality assurance process. As a part of these processes all the degrees issued by these countries are validated by the national accreditation offices or agencies reliable for completing the national higher educational acts completing all the requirements set up for the higher education [30]. Students, families, the actors of the labour market and last but not least the representatives of a country (including the Parliament and the Government as well) have trust in this kind of accreditation process because it is strictly based on law and the processes of the accreditation is clear for every actor of the higher educational system.

In several cases the students have to pay for different services in the higher educational institutions and a significant part of them have to pay a kind of tuition fee. Walsh and her co-authors investigated the students' willingness to pay for higher education and they published several important findings. As they pointed out the students' willingness to pay mostly depends on the region of their origin, their academic abilities and their socio-economic status. Students with better academic ability are willing to pay more for higher quality education and services while students with weaker academic abilities are not willing to pay more just because of the education quality. The role of the socio-economic status in the willingness to pay is crucial because the analysis showed a very important result when it clarified that the students with lower socio-economic status are also willing to pay for higher education. That means studying can be defined as an 
investment in human capital. On the other hand it is unequivocal that in several cases the parents are covering the students' tuition fees [31]. When the families decide to finance the studies they can make their decisions on different basics. The role and the importance of fact-based decision making in case of the agriculture reduced in the last period which can effect on the career planning of the secondary school students as well. Mostly those people have relevant knowledge about the agriculture who are somehow involved which can also have effect on the directed recruitment of the agricultural professionals [32]. It cannot be written down too often that investment in a diploma is a very important decision not only for a student but for the whole family. This statement is even truer in those countries where the tuition fees or the additional costs of the higher educational studies represent a higher part of the family monthly or yearly incomes.

The size of the country and the importance of the agriculture in the national GDP can have effects on the number of students in the agricultural higher education but not in every case. In the United States of America altogether more than 125000 students used to study on different higher educational programs in 2015. In Germany this number reached the 45000 students which is much more than it should be if we count a ratio from the size or total population of the USA and Germany. In Hungary more than 9000 students are studying in different agricultural higher educational programs while in Denmark where the importance of the agriculture and its share in the national GDP is much higher this number is only around 5500 - however Hungary is twice bigger and have a population of nearly twice more than Denmark has [33].

To transfer the most actual knowledge for the students is one of the most important aims of the higher education. Practice oriented programs have to be started in every higher educational system and they have to be developed continuously. Where the three-tier higher educational system have been involved after 2006 the reform of the higher educational system should have been evaluated. If it seemed to be effective the one-tier master programs should have been re-organised in the agriculture as well. The future's agriculture needs well educated mechanical engineers with technical and informatics knowledge and managers with high quality fiscal and economic knowledge as well. It is important to keep in mind the global trends of the agriculture, where the countries with less developed agriculture should pay attention for the new inventions introduced in the developed agricultural systems. That means the countries with less developed agricultural system have to find those parts of the developed agricultural systems which are able to get implemented there [34].

During the development of the educational system we always have to pay attention for the needs of the labour market otherwise the students who graduate on different levels of the educational system will not be employed. Overand under-education can be present in the same country at the same time, parallel [35]. The lifelong learning became the most important motivator of the educational development in the last decades. The educational policy of the European Union pays attention for this topic and this tendency have great influence on the member states' educational systems as well. The lifelong learning as a possibility absolutely harmonises with the needs of the modern society and with the modern agricultural system as well and can be listed as one of the most important elements of the modern educational policy. The lifelong learning can be the bridge between the higher educational system and the labour market [36] as it is able to lead more students to the higher education and it is able to transfer the most actual knowledge from the scientific life to practice. It is important to declare that not only formal educational institutions can participate the lifelong learning process in the educators' role but other institutions, organisations or individuals can do this as well as informal or non-formal educators serving the needs of the different sectors including agriculture.

The future of the agriculture is also in lifelong learning. This way the education can become a symbol of the loyalty and solidarity of the employee to the employer. On the other hand the need and the demand for the knowledge as a product increased which can have a positive impact on the quality and quantity development of the offered educational programs and services [37].

\section{CONCLUSION}

The agriculture needs the help of higher education worldwide. In the less developed countries the adaption of the actual technologies can serve the needs of the local agriculture. In developed countries the agricultural workforce needs to be educated continuously in order to keep their knowledge fresh. New knowledge, new skills and new competencies: these are the things a modern famer need continuously during her or his career in the agriculture.

In this article we analysed the agricultural higher education and its impact on the agricultural production. The agricultural higher educational system have to be reformed in order to keep it updated. Without the needed reform the higher education will not be able to serve the needs of the agricultural labour market. Lifelong learning activities can help to complete these needs but the pedagogical knowledge of the teachers and academic staff members are also very important.

\section{CONFLICT OF INTEREST}

The authors declare no conflict of interest.

\section{ACKNOWLEDGMENT}

"Supported by the ÚNKP-18-3 New National Excellence Program of the Ministry of Human Capacities".

\section{REFERENCES}

[1] P. M. Kömíves, P. Körösparti, and P. Pilishegyi, "Restructuring the functions of the hungarian higher educational system after 2006," Current and Emerging Themes in Global Access to Post-Secondary Education, Emerald Publishing, Bingley, pp. 39-47, 2017.

[2] A. Herneczky and S. Marselek, "Dilemmas in hungarian higher education," Gazdálkodás, vol. 53, no. 23, pp. 14-25, 2009.

[3] A. Abbas, "The agricultural education in the republic of Iraq," Scientific Papers Series Management, Economic Engineering in Agriculture and Rural Development, vol. 17, no. 1. pp. 11-20, 2017.

[4] A. F. Fieldsend and J. Nagy, "Constraints on rural entrepreneurship in Eastern Hungary," Journal of Central European Agriculture, vol. 7, no. 3. pp. 529-532, 2006. 
[5] J. W. Jones et al., "Brief history of agricultural system modelling," Agricultural Systems, vol. 155, 2016, pp. 240-254.

[6] J. Popp et al., "The effect of bioenergy expansion: Food, energy and environment," Renewable and Sustainable Energy Reviews, vol. 32, 2014, pp. 559-578.

[7] J. Tóth and I. Fertö, "Innovation in the Hungarian food economy," Agricultural Economics (Zemedelska Ekonomika), vol. 63, no. 1, pp. 43-51, 2017.

[8] FAO - IFAD - UNICEF - WFP - WHO (2018), The State of Food Security and Nutrition in the World 2018. Building Climate Resilience for Food Security and Nutrition, FAO, Rome.

[9] J. Horváth, “A mezögazdaság föbb ágazataival kapcsolatos kilátások a világon," A világ mezögazdaságának fejlödési tendenciái. Szegedi Tudományegyetem Mezőgazdasági Kar, Hódmezővásárhely, 2016.

[10] M. Maciejczak et al., "Use of smart innovations for development of climate smart agriculture," Roczniki Naukowe Stowarzyszenia Ekonomistów Rolnictwa i Agrobiznesu, vol. 20, no. 2. pp. 117-124, 2018.

[11] G. Kemény, "Precision agriculture in Hungary: Assessments of perceptions and accounting records of FADN arable farms," Studies in Agricultural Economics, vol. 120, 2018, pp. 47-54.

[12] C. Cavicchi and E. Vagnoni, "Intellectual capital in support of farm businesses' strategic management: a case study," Journal of Intellectual Capital, 2018.

[13] I. Szücs et al., "Az agrárgazdaság hatékonyságának néhány sajátos aspektusa," Gazdálkodás, vol. 58, no. 6, pp. 564-594, 2014.

[14] P. Heisey et al., ASTI Global Assessment of Agricultural R\&D Spending Developing Countries Accelerate Investment, 2012.

[15] P. G. Pardey et al., "Agricultural production. Productivity and R\&D over the past half century: An emerging new world order invited plenary paper," presented at the International Association of Agricultural Economists (IAAE) Triennial Conference, Foz do Iguaçu, Brazil, 2012.

[16] S. Mészáros and G. Szabó, "Vitazáró: hatékonyság és foglalkoztatás a Magyar mezőgazdaságban," Gazdálkodás, vol. 59, no. 2, pp. 175-188, 2015.

[17] J. Popp and M. Harangi-Rákos, “A szarvasmarhatenyésztés nemzetközi és hazai kilátásai," Állattenyésztés és Takarmányozás, vol. 62, no. 4, pp. 324-345, 2013

[18] R. Radhakrishna and J. Ewing, "A framework for implementing learning outcome assessment (LOA) in agricultural education programs," The Agricultural Education Magazine, vol. 90, no. 1, pp. $15-17,2017$.

[19] A. H. Rice and T. Kitchel, "The relationship between agricultural knowledge bases for teaching and sources of knowledge," Journal of Agricultural Education, vol. 56, no. 4, pp. 153-168, 2015.

[20] C. R. Kothari, Research Methodology. Methods \& Techniques, New Age International Publishers, New Delhi, 2004

[21] R. K. Barrick, "Agricultural education: building upon our roots," Journal of Agricultural Education, vol. 30, no. 4, pp. 24-29, 1989.

[22] C. Laurent et al., "Agricultural extension services and market regulation: Learning from a comparison of six EU countries," The Journal of Agricultural Education and Extension, vol. 12, no. 1, pp. 5-16, 2006.

[23] B. Surányi, "A magyar mezőgazdasági szakoktatás története 1945-ig, különös tekintettel a debreceni agrár-felsőoktatásra," Gerundium, vol. 9, no. 1, pp. 81-115, 2018

[24] C. Mougenot et al., "From agricultural education to the environment. New challenges new identities...," European Journal of Agricultural Education and Extension, vol. 2, no. 1, pp. 37-47, 1995.

[25] J. C. Kalla, "Planning agricultural education in India," European Journal of Agricultural Education and Extension, vol. 4, no. 1, pp. 67-80, 1997.

[26] L. Csete, "Oktatás, képzés: út a jövő mezőgazdasága felé," Gazdálkodás, vol. 62, no. 2, pp. 178-187, 2018.

[27] I. Kapronczai, “A hazai agrárképzés korlátai," Gazdálkodás, vol. 62, no. 5, pp. 459-476, 2018.

[28] E. Balázs, “Tömegoktatás, elitoktatás és a minőség," Educatio, vol. 23, no. 4 , pp. $550-554,2014$

[29] J. Varga, "A képzési terület és a felsőoktatási intézmény hatása a fiatal diplomások munkaerő-piaci sikerességére a 2000-es évek végén," Budapest Working Papers on the Labour Market, No. BWP, 2010.

[30] S. Schwarz and D. S. Westerheijden, "Accreditation in the framework of evaluation activities: A comparative study in the European Higher Education Area," Accreditation and Evaluation in the European Higher Education Area, Springer, pp. 1-41, 2004.
[31] S. Walsh et al., "Exploring heterogeneity in willingness to pay for the attributes of higher education institutions," Oxford Economic Papers, 2018, pp. 1-22.

[32] K. Mittenzwei et al., "Hot cognition in agricultural policy preferences in Norway?" Agricultural Human Values, 2016, vol. 33, pp. 61-71.

[33] OECD. (2019). [Online]. Available: https://www.stats.oecd.org

[34] S. Magda et al., "Az agrárgazdaságban foglalkoztatottak képzettsége és a jövő igénye," Gazdálkodás, vol. 61, no. 4, pp. 61-86, 2017.

[35] G. Velkey, Dinamikus Egyensúlytalanság. Hungarian Academy of Sciences, Budapest, 2013.

[36] P. M. Kőmíves and K. Dajnoki, "Élethosszig tartó tanulás: híd a munkaerőpiac és a felsőoktatás között," Taylor Gazdálkodás- és Szervezéstudományi Folyóirat, vol. 8, no. 4. pp. 86-94, 2016.

[37] A. Óhidy. (2012). Az élethosszig tartó tanulás és a felnőttképzés. [Online].

Available: http://epa.oszk.hu/00000/00035/00107/2006-10-31-Ohidy-Elethosszi g.html

Copyright $\odot 2019$ by the authors. This is an open access article distributed under the Creative Commons Attribution License which permits unrestricted use, distribution, and reproduction in any medium, provided the original work is properly cited (CC BY 4.0).

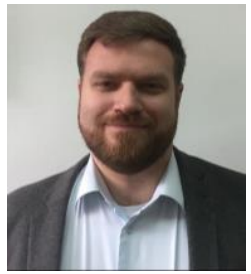

Péter Miklós Kỏmíves is a lawyer (MA), communication and media expert (MA) and higher education and scientific manager (post-master degree). He graduated at the University of Debrecen, Hungary, at the Corvinus University of Budapest, Hungary and at the Loránd Eötvös University, Hungary. $\mathrm{He}$ has a $\mathrm{PhD}$ absolutorium in management and business from the Károly Ihrig Doctoral School of Management and Business, University of Debrecen, Hungary. His most important research topic is the internationalization of the higher education in Hungary.

$\mathrm{He}$ is an assistant lecturer of the University of Debrecen, Faculty of Economics and Business and a doctoral candidate of the University of Debrecen. As an assistant lecturer he teaches several courses titled human resources management, lifelong learning practices, learning organizations, quality management, labour policy, labour relations, communication etc. He has several publications about higher educational, labour market and migration issues partly related with agriculture, quality assurance and international mobility both in English and in Hungarian. He often participates in domestic and international conferences in his research topics as a presenter, session chair or committee member.

Dr. Kömíves used to serve as the President of the National Union of PhD and DLA Candidates of Hungary and as the Treasurer (Board Member) of the EURODOC. In 2017-2018 he was a member of the Hungarian Accreditation Committee Expert Committee of Humanities. He is a member of the Association of Hungarian Agricultural Economists (MAKE) and of the European Association of Agricultural Economists (EAAE). Ha has been awarded with the New National Excellence Program Grant in the academic year of 2018/2019. He has been awarded with the Pro Auditoribus Universitas Debreceniensis Award by the University of Debrecen.

Péter Pilishegyi is an economist (MA), political scientist (BA) and higher education and scientific manager (post-master degree). He graduated at the University of Debrecen, Hungary, and at the Loránd Eötvös University, Hungary. He has a PhD absolutorium in history from the Doctoral School of History and Ethnography, University of Debrecen, Hungary. His most important research topic is the history of the higher education in Hungary. $\mathrm{He}$ is the director of the Centre of Student Services and Relations at the University of Debrecen since 2008. He has several publications about higher educational, labour market and migration issues both in English and in Hungarian. He often participates in domestic and international conferences in his research topics as a presenter.

Mr. Pilishegyi used to serve as the vice-president of the Student Council of the University of Debrecen. He has been awarded with the Pro Auditoribus Universitas Debreceniensis Award and the Certificate of Merit of the Rector by the University of Debrecen.

Norbert Novák is an agricultural engineer (MSc), and economist of business development (MA). He graduated at the University of Debrecen, Hungary.

$\mathrm{He}$ is going to the first year of $\mathrm{PhD}$ in rural development from the the Károly Ihrig Doctoral School of Management and Business, University of Debrecen, Hungary. His main research topic is the development potential of the Hungarian countryside. He teaches several courses related to the rural development. He often participates multinational conferences. 
Mr. Novák is the board member of the local government of $\mathrm{PhD}$ students. $\mathrm{Ha}$ has been awarded with the EFOP-3.6.1-16-2016-00022 Debrecen Venture Catapult Program Grant in the academic year of 2018/2019. He has been awarded with the Pro Facultate Iuventutis Award by the Faculty of Economics and Business, University of Debrecen.

Adrián Szilárd Nagy is an agricultural economist (MA), Master of Business Administration (MBA) and entrepreneurial management expert (post-master degree). He graduated at the University of Debrecen, Hungary and at the International MBA Network. He has a PhD degree in management and business from the Károly Ihrig Doctoral School of Management and Business, University of Debrecen, Hungary. His most important research topic is the effective operation of a family business.

$\mathrm{He}$ is an associate professor of the University of Debrecen, Faculty of Economics and Business. As an Associate Professor he teaches several courses titled project management, media economics, business management, enterprise development policy, business planning etc. He is the supervisor of several doctoral students at the Károly Ihrig Doctoral School of Management and Business, University of Debrecen, Hungary. He has several publications about family business, tourism, higher education and project management both in English and in Hungarian. He often participates in domestic an international conferences in his research topics as a presenter, session chair or committee member.

Dr. Nagy used to serve as the President of the student council of the University of Debrecen. He is a member of the public body of the Hungarian Academy of Sciences and the Academic Committee of Debrecen. He has been awarded with the Pro Universitate Juventutis Award and the Pro Educatione Oeconomicae Award by the University of Debrecen.

Péter Körösparti is a historian (MA), teacher of history (MA), ethnographer (MA), political scientist (BA) and higher education and scientific manager (post-master degree). He graduated at the University of Debrecen, Hungary and at the Loránd Eötvös University, Hungary. He has a $\mathrm{PhD}$ absolutorium in management and business from the Károly Ihrig Doctoral School of Management and Business, University of Debrecen, Hungary. His most important research topic is quality assurance policies of the higher education in Hungary.

$\mathrm{He}$ is the deputy director of the Centre of Student Services and Relations at the University of Debrecen. He has several publications about higher educational, labour market and quality assurance issues partly related with international mobility both in English and in Hungarian. He often participates in domestic and international conferences in his research topics as a presenter.

Mr. Körösparti used to serve as the President of the National Union of Students of Hungary. In 2013-2015, he was a member of the Higher Education Planning Council of the Hungarian Government. He also served as the President of the student council of the University of Debrecen. He has been awarded with the Pro Auditoribus Universitas Debreceniensis Award by the University of Debrecen and the Certificate of Merit of the Defence Minister of Hungary. 